\title{
The enigma of fluency: a single case study
}

\author{
Tessa Goldsmith BA (Sp \& H Therapy) (Witwatersrand) \\ Denise Anderson BA (Sp \& H Therapy) (Witwatersrand) \\ Department of Speech Pathology and Audiology, \\ University of the Witwatersrand, Johannesburg
}

\begin{abstract}
The article deals with the relapse and maintenance of fluency skills in an adult stutterer following a "fluency-based" treatment programme. Recordings of speech were made at relevant intervals throughout an eight month period. Immediately after intensive treatment, fluency was established and rate and attitudes normalized. The deterioration of these behaviours and their re-instatement is described.
\end{abstract}

\section{OPSOMMING}

Die artikel handel oor die insinking en behoud van vlotheidsvaardighede in 'n volwasse hakkelaar na 'n "vlotheid-gebaseerde" terapie program. Spraakopnames is met gereelde tussenposes gedurende 'n agt maande periode gedoen. Spraakvlotheid is kort na die intensiewe behandelingsperiode bereik, terwyl spraakspoed and houdings genormaliseer is. Die agteruitgang van bogenoemde gedragspatrone en die herinstelling daarvan word beskryf.

One of the most perplexing aspects of the stuttering problem reflected by clinical experience and in the literature, is the relative ease with which most stutterers can become temporarily fluent.

The novel conditions identified as inducing fluency in the speech of stutterers have been explored, among others by Bloodstein (1950), Wingate (1969) and Andrews, Howie, Dosza and, Guitar (1982). Several explanations have been proposed for the reduction in stuttering. Bloodstein (1950) suggested that stronger or unusual stimulation could account for the change while Van Riper (1973) cited the distraction phenomenon as being responsible. Perkins, Rudas, Johnson, Michael and Curlee (1974) hypothesized that fluency inducing conditions facilitate among other features, slowing of transitions, reduced grammatical complexity and decreaséd frequency of voice onset co-ordination. Wingate (1969) concluded from his review of the literature that fluency is induced as a result of an alteration in the manner of vocalization.

Despite the simplicity of achieving immediate fluency, its permance remains elusive for the stutterer. Remediation is a controversial issue as highlighted relatively recently by Gregory (1979) in his description of the "speak-more-fluently" as opposed to the "stutter-more-fluently"-paradigm.

As regards the former, Miller (1981) states that all fluency-based programmes have in common, decreased speech rate, fewer stress contrasts and continuous breath flow, which permit the stutterer more time to co-ordinate his systems of respiration, articulation and phonation for speech production. Proponents of this approach to remediation are Perkins et al. (1974),
Schwartz (1976), Shames and Florance (1980), Webster (1980) and Goldberg (1983), among others.

The establishment of fluency restricted to clinic situations is meaningless, unless satisfactory schedules for its transfer and maintenance are executed. According to Boberg, Howie and Woods (1979) accounts of successful stuttering therapy are frequently reported before long term outcome is evaluated.

The integration of fluency is compounded by the inevitability of the relapse phenomenon. Although it has been alluded to frequently, relapse has seldom been investigated experimentally, particularly in relation to the subsequent reinstatement of the fluent response. Documented treatment failure may facilitate the recognition of significant features relating to the relapse and maintenance of fluency. It is with this aim in mind that the present single case study is presented.

\section{DESCRIPTION OF SUBJECT}

The subject was a 19 year old male university student who had stuttered since early childhood. No family history of stuttering was reported. The subject stated that he was not initially concerned about his stuttering. He had received intermittent speech therapy for about ten years and occasionally, brief remissions had occurred. The most recent intervention included efforts at direct modification of the severe stuttering symptom and acceptance of this speech pattern.

\section{PROCEDURE}

MEASUREMENT

Over the eight month intervention period, speech measurements were made at five intervals relevant to the therapeutic 
process i.e. base-line, eight weeks post-onset intervention, at relapse, post-relapse and at follow-up (see Figure 1). These measurements involved both the frequency of stuttering (percentage of syllables stuttered - \% SS) as well as speaking rate (number of syllables spoken per minute - SPM). Only the former appears in Figure 1 as this is regarded as the most explicit measure of speech progress. The speech sample consisted of two-hundred words of spontaneous speech and two-hundred words of oral reading.

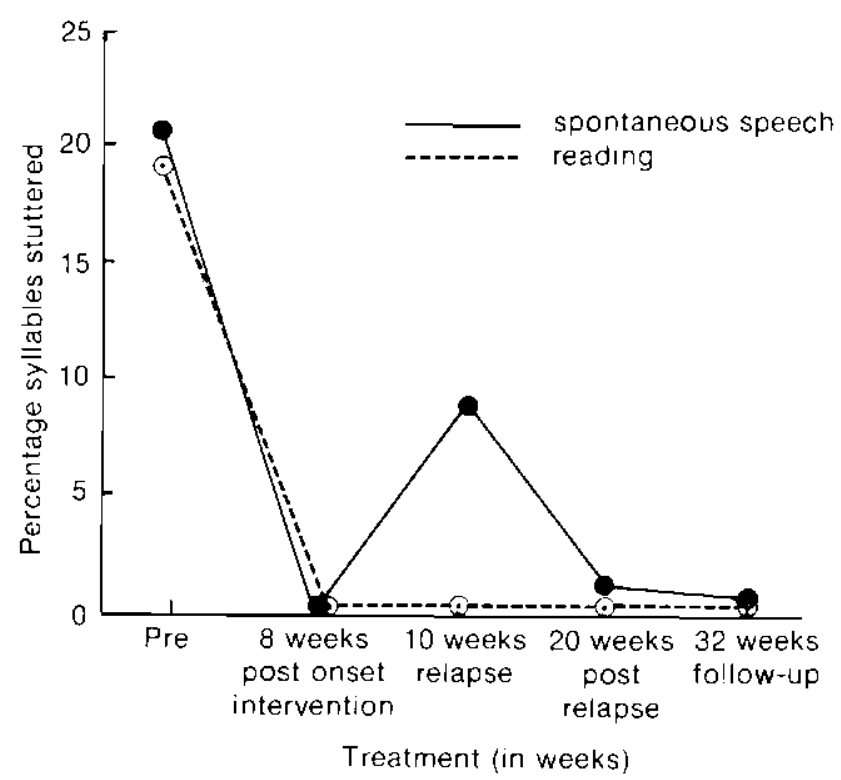

Figure 1 Percentage syllables stuttered of spontaneous speech and reading samples over the 8 month period of therapy.

The frequency of stuttering and the speaking rate were calculated according to the formulae suggested by Andrews and Ingham (1972). A general impression of prosody (including melody, inflection and stress) was formed on the basis of the spcech samples.

To establish the reliability of these measures, interjudge agreement was determined in terms of percentage concurrence. The authors listened simultaneously to the recordings and made independent judgements of the occurrences of these behaviours. Dysfluency was defined as instances of part-word repetitions, whole word repetitions, interjections, revisions, tense pauses and dysrhythmic phonation (Adams, Sears and Ramig, 1982). Over the five recording periods, the mean percentage agreement for \%SS was $88 \%$, and $93 \%$ for SPM. Perceptions of prosody were discussed until consensus was reached.

\section{Base Line Evaluation}

The subject stuttered on $20,4 \%$ of syllables during spontaneous speech and $18,3 \%$ SS during reading. According to Wingate's (1976) Severity Rating Guide, he presented as a severe stutterer. His speech was characterised by predominantly tense syllable and sound repetitions, laryngealization, and extreme difficulty initiating phonation. Stuttering occurred primarily on vowels, nasals, glides and on the first sound and syllable within words. Associated secondary features included loss of eye-contact during the moment of stuttering, fidgeting and touching his body. Avoidance and starter techniques, especially interjections, were frequently observed. He spoke at a normal rate of 196 SPM (mean rate per minute has been defined as $200 \pm 34$ syllables, Andrews and Ingham, 1972) and was monotonous when he stuttered and when he was fluent (see Table 1).

To determine the optimal fluency inducer to be used as a basis for intervention, the subject's response was assessed under the conditions outlined by Andrews et al (1982). Fluency was induced by slowing speech rate and prolonging phonation.

The subject obtained a low score on Erickson's Scale of Communicative Attitudes (1969) which is indicative of a positive attitude towards communication. It is clinically significant, relative to the severity of the stuttering symptom, that he also perceived his stuttering as mild in most speaking situations. This positive communicative attitude belies the fact that the subject reported few social interactions generally.

\section{Intervention}

As mentioned above, slowing speech rate and prolonging phonation induced fluency in this subject. He was therefore enrolled in the Stutter-Free Speech programme (Shames and Florance, 1980) which focuses essentially on these behaviours. He made a commitment to the intensive schedule of therapy and home practice. Briefly, the aims of this programme are to establish speech that is free from stuttering and a selfperception that is compatible with this new speaking behaviour. The therapy programme is comprised of five overlapping phases, involving the principles of operant conditioning to shape forward moving speech with continuous phonation and controlled speech rate.

The following alterations were made to Shames and Florance's (1980) original Stutter-Free Speech programme:

- Delayed auditory feedback was excluded as the subject was able to achieve the target response through imitation of the clinician.

Table 1 Summary of speech measurements over the 8 month intervention period

\begin{tabular}{|c|c|c|c|c|}
\hline $\begin{array}{l}\text { TIME OF } \\
\text { EVALUATION }\end{array}$ & SAMPLE & $\begin{array}{l}\text { PERCENTAGE } \\
\text { SYLLABLES } \\
\text { STUTTERED }\end{array}$ & $\begin{array}{l}\text { SYLLABLES } \\
\text { PER MINUTE }\end{array}$ & PROSODY \\
\hline $\begin{array}{l}\text { BASE-LINE } \\
\text { EVALUATION }\end{array}$ & $\begin{array}{l}\text { Speech } \\
\text { Reading }\end{array}$ & $\begin{array}{l}20,4 \\
18,3\end{array}$ & $\begin{array}{l}196 \\
187\end{array}$ & $\begin{array}{l}\text { monotone } \\
\text { monotone }\end{array}$ \\
\hline $\begin{array}{l}8 \text { WEEKS } \\
\text { INTERVENTION }\end{array}$ & $\begin{array}{l}\text { Speoch } \\
\text { Reading }\end{array}$ & $\begin{array}{l}0 \\
0\end{array}$ & $\begin{array}{l}170 \\
170\end{array}$ & $\begin{array}{l}\text { normal } \\
\text { normal }\end{array}$ \\
\hline $\begin{array}{l}10 \text { WEEKS } \\
\text { (RELAPSE) }\end{array}$ & $\begin{array}{l}\text { Speech } \\
\text { Reading }\end{array}$ & $\begin{array}{c}8,3 \\
0\end{array}$ & $\begin{array}{l}200 \\
170\end{array}$ & $\begin{array}{l}\text { normal } \\
\text { normal }\end{array}$ \\
\hline $\begin{array}{l}20 \text { WEEKS } \\
\text { (POST-RELAPSE) }\end{array}$ & $\begin{array}{l}\text { Speech } \\
\text { Reading } \\
\text { Covert } \\
\text { speech } \\
\text { recording }\end{array}$ & $\begin{array}{l}1,2 \\
0 \\
6,5\end{array}$ & $\begin{array}{l}179 \\
164 \\
174 \\
\end{array}$ & $\begin{array}{l}\text { normal } \\
\text { normal } \\
\text { normal }\end{array}$ \\
\hline $\begin{array}{l}32 \text { WEEKS } \\
\text { (FOLLOW-UP) }\end{array}$ & $\begin{array}{l}\text { Speech } \\
\text { Reading } \\
\text { Covert } \\
\text { speech } \\
\text { recording }\end{array}$ & $\begin{array}{l}0,6 \\
0 \\
1,8\end{array}$ & $\begin{array}{r}180 \\
175 \\
190\end{array}$ & $\begin{array}{l}\text { normal } \\
\text { normal } \\
\text { normal }\end{array}$ \\
\hline
\end{tabular}

The South African Journal of Communication Disorders, Vol. 31, 1984 
- Non-verbal signalling (overt hand movement) was omitted during the self-monitoring phase as it was feared that it would become a distraction.

Establishment of voluntary control of speech was achieved within a three week period of intensive therapy for an hour a day. The subject moved smoothly through the transfer phase experiencing stutter-free speech in all pre-planned contract activities.

\section{Eight Weeks Post-Onset Intervention}

The subject was speaking with $0 \%$ syllables stuttered, normal prosodic features and at a rate of 170 syllables per minute (refer to Table 1). Approximately fifty percent of his speech was monitored and fifty percent unmonitored i.e. coincidental fluency.

At this stage, the subject was enrolled into a group of adult stutterers, the aims of which were to provide peer support and the opportunity to practice monitored speech.

\section{Ten Weeks Post-Onset Intervention (Relapse)}

The newly learnt speech pattern was transient since the subject began to experience difficulty initiating phonation. Marked laryngeal tension, infrequent tense repetitions, sporadic blocks and hesitations were observed. Moreover, the subject was unable to reinstate monitored speech despite considerable effort and motivation. His speaking rate had increased to preintervention levels which obviated the previously established voluntary control. Stuttering increased as a result but relative to the base-line evaluation, these instances were reduced in frequency, were less pronounced and involved less physical effort (Refer to Table 1).

It seemed that the subject's success in the maintenance phase led to a false sense of security and reduced attention to monitored speech. This is compatible with the concept of "lucky fluency" (Perkins, 1981). In addition, environmental events probably instrumental in maintaining the off-target behaviour included the subject's prolonged illness and mid-year examinations at that time.

To reinstate the target response, the subject was encouraged to isolate the circumstances in which relapse occurred and the frequency and consequences of its occurrence. In addition to the strategies recommended by Shames and Florance (1980), intensive therapy was reintroduced and pre-planned contracts were rescheduled. The subject's awareness of his off-target behaviour was increased in an attempt to prevent further relapse.

\section{Twenty Weeks Post-Onset Intervention (Post-Relapse)}

After the re-establishment of stutter-free speech throughout the talking day i.e. at 20 weeks post-onset intervention, a further evaluation was conducted. With the aid of $75 \%$ monitored speech and $25 \%$ unmonitored speech, the percentage of syllables stuttered was reduced to $1,2 \%$ - within normal limits according to Andrews and Ingham (1972). The rate of speech was controlled at $179 \mathrm{spm}$. A comparison of these measures in relation to those conducted previously is contained in Table 1. It is interesting to note that despite the deterioration in spontaneous speech, oral reading performance remained unaffected. Fluency during oral reading was easier to establish at all phases largely because of the reduced propositionality and effective time planning it offers $\mid$ (Perkins, Bell, Johnson and Stocks, 1979).
The recency of the relapse highlighted the need for a more detailed description of the subject's reacquired fluency. Ingham and Packman (1978), Howie, Tanner and Andrews (1981) and Andrews and Craig (1982) emphasize that a comprehensive evaluation of fluency requires overt and covert assessments of speech behaviour. In operant conditioning terms, the speech clinician and the clinic become the discriminative stimuli for fluency and thus an overt recording of speech would constitute a biased evaluation of improvement.

The inclusion of a covert assessment involved the recording of a telephone conversation unbeknown to the subject. A comparison of the overt and covert recordings (contained in Table 1) revealed a discrepancy i.e. more stuttering which was probably respresentative of the subject's speech in non-clinic situations.

Furthermore, the research of Runyan and Adams (1978, 1979) and Runyan, Hames and Prosek (1982) has revealed that the speech of "successfully therapeutized" stutterers is perceptibly different from normal speakers i.e. $0 \%$ syllables stuttered and normal speaking rate do not alone constitute natural fluency.

Therefore, a perceptual evaluation of the fluency was conducted which focused on the parameters of rate, fluency, naturalness and prosody (Ingham and Packman, 1978). A spontaneous speech sample was video-recorded of six males aged between 18 and 25 years. Three of these were normal speakers and three were "successfully therapeutized" stutterers, one of whom was the subject of the study. Six speakers were chosen to provide a heterogenous matrix from which the identified subject could be objectively evaluated. The recordings were randomly presented to five unsophisticated judges, in the same session, who rated each speaker along rating scales developed for the parameters discussed above (see Fig. 2). No case history information was provided so that the judges' ratings would not
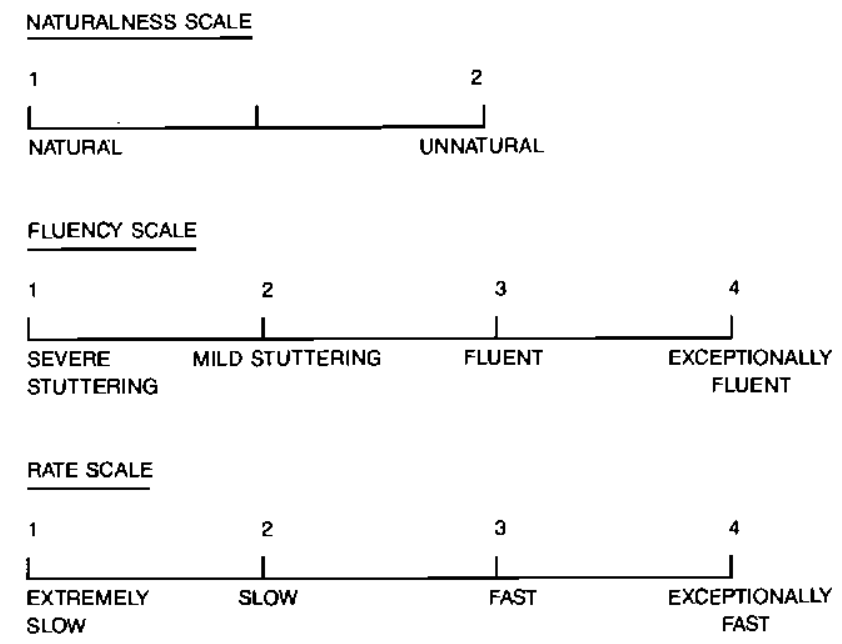

PROSODY SCALE

$\begin{array}{lccc}1 & 2 & 3 & 4 \\ \text { EXTREMELY } & \text { MONOTONOUS } & \text { EXPRESSIVE } & \text { EXTREMELY } \\ \text { MONOTONOUS } & & & \text { EXPRESSIVE }\end{array}$

Figure 2 Rating scales for perceptual evaluation (after Ingham and Packman, 1978) 
be contaminated. While the ratings of all the speakers carry clinical and theoretical significance, only the identified subject will be discussed for the purposes of this paper.

A mean score was computed for each speaker on each parameter. Overall agreement was calculated in terms of percentage of agreement between judges and was found to be $90 \%$.

The judges perceived the subject as an unnatural speaker, with mild stuttering, slow speaking rate and monotonous speech (refer to Table 2). The presence of these abnormal features aroused concern in view of Adams and Runyan's (1981) consideration of the subtle signs of fluency which they stress are important precursors to relapse. Having detected these behaviours, additional maintenance strategies were introduced focusing on the more subtle areas of natural speech. Through the use of audio-visual techniques, the subject's laboured rate, excessive monotone and instances of "microstutterings" (Boberg et al. 1979) were modified.

Table 2 Mean ratings of perceptual evaluation at relapse

\begin{tabular}{|l|c|c|c|c|c|c|}
\cline { 2 - 8 } PARAMETER & SUBJECT & NS1 & NS2 & NS3 & STS1 & STS2 \\
\hline NATURALNESS & 2 & 1 & 1 & 1 & 1 & 2 \\
\hline FLUENOY & 2 & 3 & 2 & 3 & 2 & 3 \\
\hline RATE & 2 & 3 & 3 & 3 & 3 & 2 \\
\hline PROSODY & 2 & 3 & 3 & 3 & 3 & 1 \\
\hline
\end{tabular}

NS - Normal Speaker

STS - "Successfully Therapeutized" Stutterer

\section{Thirty-Two Weeks (Follow-Up)}

Therapy contact was discontinued at this point as the subject was on a three-month vacation. Subsequent to his return, i.e. eight months after the commencement of the intervention, a complete follow-up evaluation was conducted. As displayed in Tables 1 and 3, the subject maintained fluency with normal rate and prosody in spontaneous speech and reading samples. In contrast to the previous evaluation, the present results of the overt and covert measures were consistent. In addition, the subject was now perceived as a natural speaker with normal fluency, and with normal rate and prosody relative to the matrix of normal speakers in the sample.

Table 3 Mean ratings of perceptual evaluation at follow-up

\begin{tabular}{|l|c|c|c|c|c|c|}
\hline PARAMETER & SUBUECT & NS1 & NS2 & NS3 & STS1 & STS2 \\
\hline NATURALNESS & 1 & 1 & 1 & 1 & 1 & 2 \\
\hline FLUENCY & 3 & 3 & 3 & 3 & 2 & 2 \\
\hline RATE & 2 & 2 & 2 & 2 & 2 & 2 \\
\hline PROSODY & 2 & 3 & 2 & 3 & 2 & 2 \\
\hline
\end{tabular}

NS - Normal Speaker

STS - "Successfully Therapeu-

\section{DISCUSSION}

tized" Stutterer

Although fluency was achieved and speech rate and attitudes normalised i.e. the ultimate therapy goals realised, the writers prefer to consider the clinical insights raised by the elusiveness of fluency. It is well documented that the establishment of fluency is a relatively uncomplicated procedure. However, the complexity of the client's integration of this fluency into his total life system together with the psychological adaptation involved, cannot be underestimated.

Intensive operant conditioning programmes frequently set $0 \%$ SS as the target for stutter-free speech (Howie et al. 1981; Goldberg, 1983). Other programmes permit up to 2 and $3 \%$ SS as falling within the normal non-fluency range (Hanna and Owen, 1977). Although the subject had achieved these criteria for fluent speech production, he nevertheless experienced a relapse in fluency.

Varying theoretical viewpoints have been proposed which might have accounted for the deterioration of the established response in this subject. Prins (1970) has coined the term "stuttering overkill", which he sees as a by-product of intensive therapy schedules. The subject experienced a change in speech behaviour in three weeks and may not have been fully aware of how the fluency was established. Webster (1980), in support of Prins, blames the inadequate learning of fluency producing skills for the relapse and Van Riper (1973) points out that the habitstrength of the stuttering behaviour cannot be ignored.

The presence of "lucky fluency" (Perkins, 1981) is a common phenomenon experienced by many stutterers in the establishment of fluent speech. In this case, the subject felt over confident which led to a reduction in the intensity of monitored practice. Subsequently "microstutterings" (Boberg et al. 1979) developed which increased in magnitude and ultimately resulted in overt stuttering behaviour. Clinicians who overlook the presence of these "microstutterings" may not have been sufficiently rigorous in the fulfillment of performance criteria and response contingencies and thus they may be a precipitator of relapse (Shames, 1981). As illustrated by the subject of this study, lucky fluency is transient and carries with it speech that is not under the direct control of the speaker.

Collectively these correlates of relapse compound the integration of fluency. The effective management of relapse will determine the maintenance of fluency, which is described as "the perennial weak link in the therapeutic chain" (Perkins, 1979, p. 119).

Issues that face clinicians regarding relapse encompass its predictability, its prevention, its detection and its management.

As researchers are unanimous that relapse is inevitable in adult stutterers, so they agree that clients should be informed of the likelihood of its occurrence at the outset of the therapeutic process (Boberg et al. 1979; Florance and Shames, 1980; Kamhi, 1982; Perkins, 1983). Sheehan (1979) suggests that relapses should be clinically induced so that the dread of them will be lessened when they occur.

The clinician's ability to detect subtle signs of off-target behaviour will depend on the obtaining of a representative sample of speech behaviour, especially as clinic speech performance alone is not a valid indication of therapy outcome. It is possible that the extent of this subject's relapse could have been minimized had more refined and detailéd speech measures been conducted early on in the therápeutic process. Andrews and Ingham (1972) and Andrews and Craig (1982) advocate the use of non-clinic covert speech recordings in single case studies. Despite the fact that covert assessment is 
fraught with ethical problems, the discrepancy between the subject's overt and covert speech performance yielded valuable clinical direction.

Subtle signs of stuttering have been termed "tenuous fluency" by Adams and Runyan (1981). Manifestations of such behaviour include the presence of monotone and rhythmicity, reduction in speaking rate, reduced vocal intensity and inappropriately placed pauses. At the time of the relapse, the subject of this study evidenced signs of all of the above-mentioned behaviours. In their article of 1981, Adams and Runyan contend that clients who show these signs of tenuous fluency are "good bets for relapse" (p. 215).

This study demonstrates that focus on speech behaviour alone does not guarantee improved speech performance. Concentrated work on aspects of psychological change is as relevant as are fluency instating procedures. "Maintenance of attitude change has been shown to parallel maintenance of speech improvement" (Dalton, 1983, p. 170). Failure to confront these changes may give the client reason to return to his previous modes of speech behaviour.

It became evident that this subject needed most support after the intensive period of therapy. At this point, the programme had to be directed specifically at his feelings about stuttering, his self concept, ideas about becoming a fluent speaker, and his perception of his role in therapy. These issues, as well as the behaviour change necessary for development of confidence to apply speech process control, occur primarily within the context of the clinical relationship.

In recent years, Perkins $(1981,1983)$ has argued strongly for the development and periodic re-evaluation of realistic goals for each client. This has emerged from his consideration of "fluency cost-effectiveness". In clients whose fluent speech is only realised through constant monitoring, the energy expended may not be commensurate with the reward of fluency. Thus fluency may become a "tiring chore" for the stutterer. Perkins (1983) makes the statement that "the expectation of permanent fluency is an expectation rarely realised" (p. 158). Perhaps it is only possible if the patient constantly uses the skills he is taught. In his therapy programme, Perkins (1981) thus establishes what he has termed "normal sounding speech" as opposed to "normal speech" behaviour. The distinction lies in the fact that normal speakers are not required to do anything special to achieve fluent speech.

Carefully structured therapy programmes do not necessarily follow the smooth implementation their descriptions suggest. It is the work on motivation, frustration, impatience and disappointment, tolerance of fluency failure, resistance to transfer and failure to use the newly acquired fluency in previously stressful speaking situations which forms the essence of therapy. Without these support skills, "clients will probably learn what to do to remain fluent without acquiring the facility to do it" (Perkins, 1983, p. 158).

\section{CONCLUSION}

This description was offered in order to capture the elusiveness of the fluent response in an adult stutterer. That it was eventually achieved is not tantamount to its permanence. Ultimately it is the individual who chooses fluency.

\section{ACKNOWLEDGEMENTS}

The authors acknowledge South African Inherited Disorders Association - Cleft Pals for their financial assistance.

\section{REFERENCES}

Adams, M. R. and Runyan, C.M. Stuttering and fluency: Exclusive events or points on a continuum. Journal of Fluency Disorders, 6, 197-218, 1981.

Adams, M. R., Sears, R. L. and Ramig, P. Vocal changes in stutterers and non-stutterers during monotoned speech. Journal of Fluency Disorders, 7, 21-35, 1982.

Andrews, G. and Craig, A. Stuttering: Overt and covert measurement of the speech of treated subjects. Journal of Speech and Hearing Disorders, 47, 96-99, 1982.

Andrews, G. and Ingham, R.J. An approach to the evaluation of stuttering therapy. Journal of Speech and Hearing Disorders, 15, 296-302, 1972.

Andrews, G. Howie, P. M., Dosza, M. and Guitar, B. E. Stuttering: Speech pattern characteristics under fluency inducing conditions. Journal of Speech and Hearing Research, 25, 208-216, 1982.

Bloodstein, $O$. A rating scale study of conditions under which stuttering is reduced or absent. Journal of Speech and Hearing Disorders, 15, 29-36, 1950.

Boberg, E., Howie, P. M. and Woods, L. Maintenance of fluency: A review. Journal of Fluency Disorders, 4, 93-116, 1979.

Dalton, P. Major issues for the therapist. In Approaches to the Treatment of Stuttering. Dalton, P. (Ed.). Croom-Helm, London, 1983.

Erickson, R. L. Assessing communication attitudes among stutterers. Journal of Speech and Hearing Research, 12, 711-724, 1969.

Florance, C. and Shames, G. Stuttering treatment: Issues in transfer and maintenance. Seminars in Speech, Language and Hearing, 1, 375-388, 1980.

Goldberg, S. A. The development of fluency through behavioral cognitive stuttering therapy. Communicative Disorders, 8 , 89-107, 1983.

Gregory, H. H. Controversial issues: Statement and review of the literature. In Controversies about Stuttering Therapy. Gregory, H.H. (Ed.). University Park Press, Baltimore, 1979.

Hanna, R. and Owen, N. Facilitating transfer and maintenance of fluency in stuttering therapy. Joumal of Speech and Hearing Disorders, 42, 65-76, 1977.

Howie, P. M., Tanner, S. and Andrews, G. Short and long term outcome in an intensive treatment program for adult stutterers. Journal of Speech and Hearing Disorders, 46, 104-109, 1981.

Ingham, R. J. and Packman, A.C. Perceptual assessment of normalcy of speech following stuttering therapy. Journal of Speech and Hearing Research, 21, 63-73, 1978.

Kamhi, A.G. The problem of relapse in stuttering: some thoughts on what might cause it and how to deal with it. Journal of Fluency Disorders, 7, 459-467, 1982.

Miller, S. Airflow therapy programs: Facts and/or fancy. Journal of Fluency Disorders, 7, 18,-202, 1982.

Perkins, W.H. From psychoanalysis to discoordination. In Controversies about Stuttering Therapy. Gregory, H.H. (Ed.). University Park Press, Baltimore, 1979. 
Perkins; W.H. Measurement and maintenance of fluency. In Maintenance of Fluency. Boberg, E. (Ed.). Elsevier, New York, 1981.

Perkins, W. H. Learning from negative outcomes in stuttering therapy: II. An epiphany of failures. Journal of Fluency Disorders, 8, 155-160, 1983.

Perkins, W. H., Rudas, J., Johnson, L., Michael, W.B. and Curlee, R. F. Replacement of stuttering with normal speech: III Clinical effectiveness. Journal of Speech and Hearing Disorders, 39, 416-428, 1974.

Perkins, W. H., Bell, J., Johnson, L. and Stocks, J. Phone rate and the effective planning time hypothesis of stuttering. Joumal of Speech and Hearing Research, 22, 747-755, 1979.

Prins, D. Improvement and regression in stutterers following short term intensive therapy. Journal of Speech and Hearing Disorders, 35, 123-134, 1970.

Runyan, C.M. and Adams, M.R. Perceptual study of the speech of "successfully therapeutized" stutterers. Journal of Fluency Disorders, 3, 25-39, 1978.

Runyan, C. M. and Adams, M. R. Unsophisticated judges' perceptual evaluation of the speech of "successfully treated" stutterers. Journal of Fluency Disorders, 4, 29-38, 1979.
Runyan, C. M., Hames, P. E. and Prosek, R. A. A perceptual comparison between paired stimulus methods of presentation of the fluent utterances of stutterers. Journal of Fluency Disorders, 7, 71-77, 1982.

Schwartz, M. F. Stuttering Solved. Lippincott, Philadelphia, 1976.

Shames, G. and Florance, C. L. Stutter-Free Speech: A Goal for Therapy. Charles E. Merrill, Ohio, 1980.

Shames, G. Relapse in stuttering. In Maintenance of Fluency. Boberg, E. (Ed.). Elsevier, New York, 1981.

Sheehan, J.G. Current issues on stuttering and recovery. In Controversies about Stuttering Therapy. Gregory, H.H. (Ed.). University Park Press, Baltimore, 1979.

Van Riper, C. The Treatment of Stuttering. Prentice-Hall Inc., New Jersey, 1973.

Webster, R. L. Evolution of a target-based behavioral therapy for stuttering. Journal of Fluency Disorders, 5, 303-320, 1980.

Wingate, M.E. Sound pattern in "artificial" fluency. Journal of Speech and Hearing Research, 12, 677-686, 1969.

Wingate, M.E. Stuttering: Theory and Treatment. Irvington Publishers Inc., New York, 1976. 


\section{Information for Contributors}

The South African Joumal of Communication Disorders publishes papers concerned with research, or critically evaluative theoretical or therapeutic issues dealing with disorders of speech, voice, hearing or language, or on aspects of the processes underlying these.

The South African Joumal of Communication Disorders will not accept material that has been published elsewhere or that is currently under review by other publications.

Form of Manuscript. Authors should submit manuscripts including artwork, tabular material and photographs etc. in triplicate (the original and two copies). Manuscripts should be double spaced with wide margins and should not exceed 20 pages. Each page should be numbered and labelled with the author's name.

Page / should contain only the article title, name of author/s, highest degree and address or institutional affiliation:

Page 2 should contain only an abstract (100 words) which should be provided in both English and Afrikaans. Afrikaans abstracts will be provided for overseas contributors.

Major headings, where applicable, should be in the order of METHOD, RESULTS, DISCUSSION, CONCLUSION, ACKNOWLEDGEMENTS and REFERENCES.

Tables and Figures should be prepared on separate sheets (one per table/figure, unless two/more are to appear together). The first author's name should appear on the back of each page in pencil. The heading for tables appears above and for figures below.

Lettering should be uniform, profesionally done and large enough to be legible after a $50 \%$ reduction in printing. Line drawings must be originals, in black ink on good quality white paper. Tables and figures should be numbered in order of appearance (with Arabic numerals). The amount of tabular and illustrative material allowed will be at the discretion of the Editor (usually not more than 6).
References. References should be cited in the text by surname of the author and date e.g. Van Riper (1971). Use all authors names the first time that the reference is used in the text. Thereafter et al. will suffice. References should be listed alphabetically in double-spacing at the end of the article. For acceptable abbreviations of names of journals, consult the fourth issue of DSH ABSTRACTS or The World List of Scientific Periodicals. The number of references should not exceed 20.

Note the following examples.

Van Riper, C. The Nature of Stuttering. Englewood Cliffs, New Jersey: Prentice-Hall, I 97 .

Sharf, G.T. Some Relationships Between Measures of Early Language. J. Speech Hear. Dis., 1972, 37, 67-74.

Crystal, D. Clinical Linguistics. Disorders of Human Communications 3. Arnold, G.E., Winckel, F \& Wyke, B.D. (Eds.). Austria Springer-Verlag, 1981.

Proofs. Galley proofs will be sent to the author wherever possible. Corrections other than typographical errors will be charged to the author.

Reprints. 10 reprints without covers will be provided free of charge.

All manuscripts and correspondence should be addressed to:

The Editor,

South African Journal of Communication Disorders.

The South African Speech and Hearing Association.

P.O. Box 31782 ,

BRAAMFONTEIN 2017, SOUTH AFRICA.

\section{Inligting vir Bydraers}

Die Suid-Afrikaanse Tydskrif vir Kommunikasieafwykings publiseer artikels oor navorsing, asook krities evaluerende artikels oor die teoretiese of terapeutiese aspekte van spraak-, stem-, gehoor- of taalafwykings, of oor aspekte onderliggend aan hierdie afwykings. Die Suid-Afrikaanse Tydskrif vir Kommunikasiëafuykings sal nie ma. teriaal aanvaar wat êrens anders gepubliseer is, of wat tans deur ander publikasies oorweeg word nie.

Vorm van die Manuskrip. Skrywers moet die manuskrip, insluitend tekeninge, tabelle en fotos ens. in triplikaat (die oorspronklike en twee afskrifte( inhandig. Die manuskripte moet dubbel-gespasieerd met breë kantlyne getik word en nie meer as 20 bladsye oorskry nie. Elke bladsy moet genommer wees en die skrywer se naam dra. Op Bladsy I moet slegs die artikel se titel, naam van die skrywer/s, hoogste graad behaal en adres of naam van betrokke geaffilieerde instansie verskyn.

Op Bladsy 2 moet slegs die opsomming (100 woorde) in Afrikaans en Engels verskyn.

Hoofopskrifie, waar van toepassing, moet in die volgorde METODE, RESULTATE, BESPREKING, GEVOLGTREKKING, ERKENNING en VERWYSINGS wees.

Tabelle en Figure moet op aparte blaaie voorberei word, (een per tabel/figuur, tensy twee of meer saam moet verskyn). Die eerste skrywer se naam moet in potlood op die keersy van elke bladsy verskyn. Die opskrif vir tabelle moet bo-aan en vir figure onder-aan verskyn. Lettertipes moet eenvormig, professioneel gedoen wees, en groot genoeg, om na $50 \%$ verkleining in druk, nog leesbaar te wecs. Lyntekeninge moet oorspronklik, in swart ink en op goeie kwaliteit wit papier gedoen wees. Tabelle en Figure noet in volgorde (Arabiese syfers) genommer word. Die hocveelheid getabuleerde en geillustreerde materiaal wat toegelaat word, word deur die Redakteur bepaal (gewoonlik nie meer as 6 nie).
Verwysings. Verwysings moet in die teks aangebring word deur die naam van die outeur en die datum te verstrek bv. Van Riper (1971). Gebruik alle outeursname wanneer dit die eerste maal aangehaal word. Daarna sal $e t a l$. voldoende wees. Verwysings moet alfabeties gerangskik word aan die einde van die artikel en in dubbelspasieëring getik word.

Voorbeeld:

Van Riper, C. The Nature of Stuttering. Englewood Cliffs, New Jersey: Prentice-Hall, 1971

Sharf, G.T. Some Relationships Between Measures of Early Language. I. Speech Hear. Dis., 1972, 37, 67-74.

Crystal, D. Clinical Linguistics. Disorders of Human Communications 3. Arnold, G.E., Winckel, F \& Wyke, B.D. (Eds.). Austria: Springer-Verlag, 1981.

Vind die lys van aanvaarde afkortinge van name van tydskrifte in $D H S$ ABSTRACTS (vierde uitgawe) of The World List of Scientific Periodicals. Die aantal verwysings mag nie 20 oorskry nie.

Proewe. Galeiproewe sal waar moontlik aan die skrywer voorgelê word vir proeflees. Onkoste van veranderinge (uitgesluit tipografiese foute) sal deur die skrywer gedra moet word.

Afdrukke. 10 afdrukke sonder buiteblaaie sal gratis aan die skrywer verskaf word.

Alle manuskripte en korrespondensie moet gerig word aan:

Die Redakteur.

Die Suid-Afrikaanse Tydskrif vir Kommunikasieafwykings,

Die Suid-A frikaanse Vereniging vir Spraak- en Geł..orheelkunde,

Posbus 31782.

BRAAMFONTEIN 2017, SUID-AFRIKA 